\title{
COMPARATIVE MORPHOLOGY OF THE PRIMARY VASCULAR SYSTEMS IN SOME SPECIES OF ROSACEAE AND LEGUMINOSAE ${ }^{1}$
}

\author{
Crispin Devadas and Charles B. Beck \\ Department of Botany, The University of Michigan, Ann Arbor 48104
}

\begin{abstract}
A B S T R A C T
The structural patterns of the primary vascular systems in some species of Leguminosae and Rosaceae have been determined by tracing the longitudinal course of the vascular bundles in terminal stem segments. These systems are interpreted as consisting of sympodia. Each sympodium is composed of an axial bundle which is continuous through the length of the segment and from which arise trace bundles that supply leaves and axillary buds. A compact arrangement of vascular bundles seems to correlate with the woody habit. Regardless of the degree of compactness of the primary vascular system, the structural identity of the individual sympodia is maintained. The total number of vascular bundles at a particular level is related to the number of axial bundles in the system, the number of traces per leaf and per axillary bud, and the number of internodes traversed by the traces prior to entering a lateral appendage. Shrubs and trees have more vascular bundles than herbs. Data from this study and the literature indicate that the vascular system is predominantly of the open type in dicotyledonous plants which have helically arranged leaves and, further, that in such plants with a 3-trace, trilacunar nodal structure, the number of sympodia coincides with the number of orthostichies (which is also the denominator of the phyllotactic fraction). In open systems leaf gaps cannot be morphologically delimited. Because of the resemblance of the open type of angiosperm vascular system to that of certain gymnosperms, previously interpreted to have evolved from a protostele, we suggest that the eustele of angiosperms is homologous with the stele of gymnosperms. We believe, also, that angiosperms, like gymnosperms, are probably not characterized by leaf gaps of filicinean type. We provide, furthermore, a rationale for the view that the axial bundle of a sympodium is a cauline structure.
\end{abstract}

Primary VASCUlar systems have been studied and interpreted in different ways by many workers. Some early plant anatomists (De Bary, 1884) considered the individual vascular bundles to be the basic unit of primary vascular construction. They believed, for example, that a single bundle of a primary vascular system consisting of many bundles, such as that of Pteridium, was the morphological equivalent of the entire protostelic vascular system in a fern such as Gleichenia. The unity of the vascular system was subsequently recognized, however, and emphasized by Van Tieghem and Douliot (1886) in their formulation of the stelar theory. Under this concept, all of the bundles in the rhizome of Pteridium, collectively, would be considered morphologically equivalent to the single vascular column of Gleichenia. The stelar concept subsequently underwent several modifications and elaborations through the work of Strasburger (1891), Jeffrey $(1899,1902)$, Gwynne-Vaughan (1901), Brebner (1902), Bower (1923), and Zimmermann (1930). Of these works,

\footnotetext{
${ }^{I}$ Received for publication 17 August 1972.

Based on a University of Michigan Ph.D. thesis by C. Devadas. Supported in part by U. S. National Science Foundation grant GB-8100X to $\dot{C}$. B. Beck. Present address of C. Devadas: Department of Botany, Madras Christian College, Madras 59, India.
}

Jeffrey's has probably had the greatest influence on contemporary thought concerning the evolution of the stele.

Jeffrey recognized two basic types of steles, the primitive protostele, and the siphonostele, derived from the former by the evolution of a pith. He interpreted the fern dictyostele to be a modified siphonostele, having become highly dissected by overlapping leaf gaps. He concluded, furthermore, that the vascular cylinder of the seed plants, namely the eustele (Brebner, 1902), was derived from the filicinean dictyostele by further reduction of the vascular tissues.

A different interpretation of the vascular cylinder of seed plants is that it consists of a number of discrete vascular bundle sympodia. Nägeli (1858) illustrated the vascular systems of several dicotyledons as cylinders of sympodia. Geyler's studies of gymnosperms (1867) yielded similar results that have been more recently corroborated by Scott (1923) and Namboodiri and Beck (1968a,b). De Bary (1884) wrote that the vascular bundles in angiosperms are connected in a unilateral sympodial manner, or in a reticulate manner. Balfour and Philipson (1962), Esau (1965b), and Benzing $(1967 \mathrm{a}, \mathrm{b})$ have also described the primary vascular systems of some dicotyledons in terms of sympodial systems. 
According to Namboodiri and Beck (1968c), who provide an alternative to Jeffrey's hypothesis of the origin of the eustele, the primary vascular system of gymnosperms, comprised of a cylinder of sympodia, has evolved directly from the protostele. This conclusion is supported by evidence from the fossil record (Beck, 1970). Beck believes, furthermore, that the interfascicular regions commonly called leaf gaps in the gymnosperm stele are not homologous with the filicinean leaf gap (Namboodiri and Beck, 1968c; Beck, 1970). If one accepts the viewpoint that angiosperms are descended from some group of gymnosperms, it seems reasonable to suspect that the eustele of angiosperms may be comparable in morphology with that of gymnosperms.

The primary objectives of this study are to carefully analyze the morphology of the primary vascular systems of members of two families of angiosperms and to consider whether or not they can be reasonably interpreted in this way. The Leguminosae and Rosaceae have been selected because they contain both woody and herbaceous members. One would expect the primary vascular systems of woody members to represent relatively primitive stelar types. Study of herbaceous and woody species in the same families might provide some information on evolutionary changes in stelar structure within the families.

MATERIALS AND METHODS-The following plants were used in this study: Cassia didymobotrya Fresen., Trifolium repens L. (Leguminosae); Physocarpus opulifolius (L.) Maxim., Prunus avium L., Rubus occidentalis L., Potentilla fruticosa L., Geum canadense Jacq. (Rosaceae). Voucher specimens are on file in the herbarium of the University of Michigan. Three to eight specimens of each species were sectioned for study. Living terminal segments of the stem, $1.5-2.0 \mathrm{~cm}$ long, were fixed in Craf 2 and Craf 3 solutions. The segments were washed in 50\% ethanol and dehydrated through an ethyl-tertiary butyl alcohol series and embedded in Tissuemat. Serial transverse sections were cut at $10 \mu$ and double stained with $1 \%$ aqueous safranin and $5 \%$ fast green in clove oil. Treatment of the fixed material in hydrofluoric acid prior to dehydration softened it and also removed some of the tannin in the tissue. Line drawings of cross sections were made with the aid of a Wild M5 drawing tube attachment.
Diagrams of the primary vascular patterns were constructed by tracing the longitudinal course of the vascular bundles in the stem. These diagrams show the vascular system as if it were split along one side, opened out, and viewed from inside. Details of this technique are provided by Devadas (1970).

Terminology-Terms are defined below in the sense in which they are used in this work:

1. Stele is the system of primary vascular bundles in the axis of the plant body.

2. Eustele is a cylinder of sympodia of vascular bundles which comprises the primary vascular system in the stem of gymnosperms and dicotyledons.

3. Leaf gap is a region of interfascicular parenchyma in the vascular cylinder opposite a diverging leaf trace.

4. Axial bundle is the major vascular bundle of a sympodium. It continues along the length of a stem segment without interruption, and from it leaf and branch traces may arise.

5. Leaf trace is a bundle which diverges from an axial bundle and extends into a leaf. This term applies to a bundle from the point of its divergence up to the level at which it enters a leaf base. Of the three traces supplying a leaf, the intermediate one is termed the median trace and the others, left and right lateral traces, depending on whether they are located on the left or right of the median trace as they appear in vascular patterns.

Description of primary vascular patterns-The species of Cassia, Prunus, Physocarpus, Rubus, and Potentilla studied are characterized by vascular systems of surprisingly similar pattern. Each is an open system consisting of five well-defined sympodia. Leaves are helically arranged in a $2 / 5$ phyllotaxy, and each species is characterized by a 3-trace, trilacunar nodal anatomy. The pattern in Cassia will be described in detail, followed by the variations in the other species.

The primary vascular system of Cassia was traced from the region where the interfascicular cambium is initiated up to the shoot apex (Fig. 1). It is an open system consisting of five sympodia corresponding to the five orthostichies. In each sympodium there is an axial bundle, several leaf trace bundles, and some branch traces. The axial bundles are continuous along the length of the

Fig. 1-3. Schematic representations of primary vascular systems shown as if split along one side and spread out in one plane. Axial bundles are drawn with thick lines and leaf and branch traces with thin lines. Triangles, crosses, and circles represent median leaf traces, lateral leaf traces, and branch traces, respectively. A, axial bundle; M, L, and R, median, left lateral, and right lateral leaf traces.-Fig. 1. Cassia didymobotrya.-Fig. 2. Trifolium repens.-Fig. 3. Rubus occidentalis. The presence of a complete complement of bundles at the upper edge of this and some other diagrams in this paper indicates the termination of the diagram below the level at which some bundles are immature. It does not indicate that all bundles are equally mature in the most apical region of the stem. 

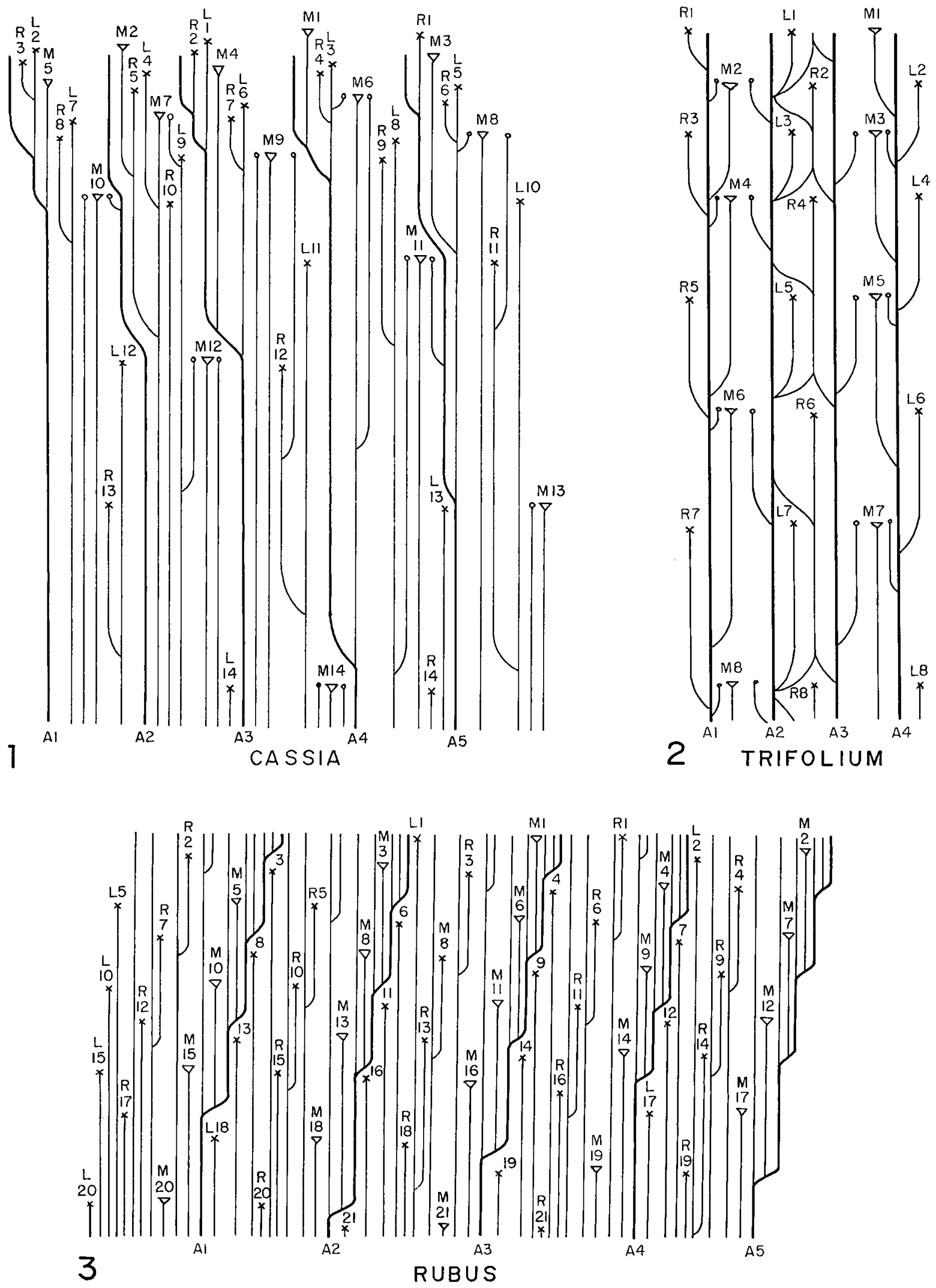
stem segment and are placed between and parallel to the orthostichies. Axial bundles, although generally continuous and discrete, may branch if there is an increase in the number of sympodia as in a seedling (Jensen, 1968), or they may fuse with change in phyllotaxy and reduction in number of sympodia as in a relatively determinate lateral shoot (see Kumari, 1963). Neither branching nor fusion of axial bundles, however, was observed in this study. Two types of leaf trace bundles diverge from each axial bundle in a regular alternating sequence. One type functions as a median leaf trace and the other type bifurcates and produces two lateral leaf traces which will supply two different leaves formed in succession along the ontogenetic spiral. The trace that is farther from the axial bundle becomes the left lateral trace of a leaf. The other one becomes the right lateral leaf trace of the next lower leaf. From the point of their divergence from the axial bundle the leaf traces traverse 5-8 internodes before entering a leaf. All leaf traces diverge in the same direction from the axial bundles. The three traces supplying a particular leaf are related to three neighbouring axial bundles. For example, the traces to leaf 12, namely, L12, M12, and R12 arise directly or indirectly from axial bundles $\mathrm{A} 1, \mathrm{~A} 2$, and $\mathrm{A} 3$ respectively (Fig. 1). A branch trace which is on the left side of the median trace diverges from a leaf trace which supplies a leaf three nodes above. The branch trace on the right side may originate from an axial bundle on its right or may branch from a leaf trace that originated at a lower level.

In Cassia, in addition, there are a large number of accessory bundles in the stem. These are usually smaller than other types of bundles, lacking any primary xylem. They are random in position in the system, variable in longitudinal extent, and commonly terminate within interfascicular parenchyma, supplying no lateral appendage. Occasionally they form connections between other bundles or fuse with each other, but there is no consistent pattern of interconnection. To avoid cluttering the diagram they have been omitted from the Cassia pattern in this paper. They have been illustrated and discussed in greater detail in Devadas. and Beck (1971).

At any given level the combined number of bundles that function as axial or leaf trace bundles remains more or less constant at about 23. Although three trace bundles enter leaf bases at every node, the number of vascular bundles in the stem remains constant because three new bundles, on the average, originate within each internode.

The vascular pattern of the stem of Prunus differs in some ways from that of Cassia. In Prunus the leaf trace bundles traverse 5-7 internodes along the stem from the point of their divergence from an axial bundle to the level at which they enter their respective leaf bases (Fig. 4). There are about 20 vascular bundles at any given level. One or two of these, depending on the level, are branch traces, five are axial bundles, and the rest are leaf trace bundles.

The vascular patterns of Physocarpus and Rubus differ from that of Cassia in that the leaf trace bundles traverse 5-27 and 8-35 internodes, respectively, before entering leaf bases (Fig. 6, 3). The three traces supplying the same leaf belong in two neighbouring sympodia. One of the laterals and the median trace bundle are connected to the same axial bundle, whereas the other lateral trace diverges from a neighbouring axial bundle. The total number of vascular bundles in the stem, as seen in cross sections, is about 32 in Physocarpus and 50 in Rubus.

Potentilla fruticosa is a shrubby perennial herb, characterized by phyllotaxy and nodal anatomy similar to those of the four previously discussed genera. However, the leaf trace bundles diverge in both directions from the axial bundles in this plant (Fig. 5).

Median trace bundles and right lateral traces diverge to the left from the axial bundles. These traces may originate as a single bundle that bifurcates, or they may diverge as separate bundles. Of the two branch traces, the one that is to the right side also diverges to the left from the axial bundles. The left lateral trace and the remaining branch traces diverge to the right from the axial bundles. The similar divergence of the several types of trace bundles is repeated at intervals of five internodes in each sympodium. The three traces supplying a particular leaf belong to three different sympodia. For example, M6 diverges from A3, R6 from A4, and L6 from A1. The median traces, after diverging from the axial bundles, are independent for four internodes before entering a leaf. The left laterals traverse two internodes, and the right laterals traverse one. Cross sections of internodal regions have about 14 vascular bundles of which one or two are branch traces, five are axial bundles, and the others are leaf trace bundles.

Trifolium and Geum are herbs characterized by alternate distichous leaves, a $1 / 2$ phyllotaxy, and a trilacunar 3-trace nodal anatomy. As in the preceding species, the vascular cylinder in the stem can be interpreted in terms of sympodial systems. Transverse sections of Trifolium taken at the middle of the internodes show about ten vascular bundles, which are well separated by interfascicular regions. Among these are four axial bundles, a pair on either side of the longitudinal plane in which the two rows of leaves occur. Sympodia 1 and 4 are on the same side of this plane and are identical to each other (Fig. 2). From the axial bundles of these sympodia, a branch trace, a lateral leaf trace, and a median leaf trace diverge in acropetal sequence, repeated regularly at alternate nodes. The lateral traces diverge from the sides of these axial bundles that 

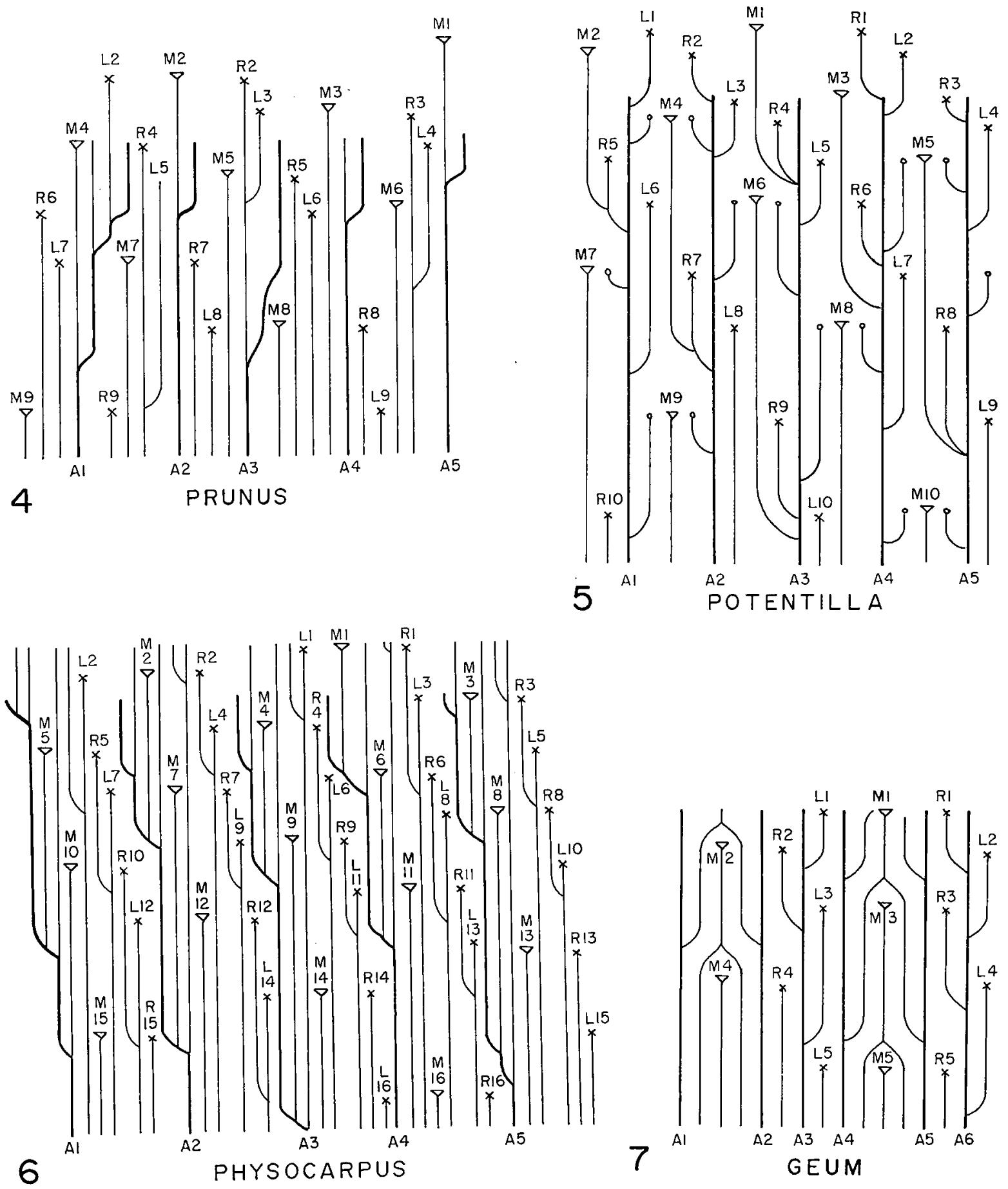

Fig. 4-7. For description, see caption to Fig. 1-3.-Fig. 4. Prunus avium.-Fig. 5. Potentilla fruticosa.-Fig. 6. Physocarpus opulifolius.-Fig. 7. Geum canadense.

face each other, whereas the median and branch traces are on the sides facing axial bundles 2 and 3 . Sympodia 2 and 3 are also similar to each other but differ from 1 and 4 . Lateral leaf traces and branch traces diverge alternately from them. The lateral traces are produced on the sides of the axial bundles that face each other, and the branch traces come off the sides toward axial bundles 1 
TABLE 1. Data on habit, phyllotaxis and the primary vascular system in the stems of some Rosaceae and Leguminosae

\begin{tabular}{|c|c|c|c|c|c|c|}
\hline Name & Habit & Phyllotaxy & $\begin{array}{l}\text { Phyllotactic } \\
\text { fraction }\end{array}$ & $\begin{array}{c}\text { Number } \\
\text { of } \\
\text { sympodia }\end{array}$ & $\begin{array}{l}\text { Number } \\
\text { of vascular } \\
\text { bundles }\end{array}$ & $\begin{array}{c}\text { Vascular } \\
\text { system } \\
\text { open/closed }\end{array}$ \\
\hline Rubus occidentalis $\mathrm{L}$. & Shrub & Spiral & $2 / 5$ & 5 & 50 & Open \\
\hline Maxim. & Shrub & Spiral & $2 / 5$ & 5 & 32 & Open \\
\hline Cassia didymobotrya Fresen. & Shrub & Spiral & $2 / 5$ & 5 & 23 & Open \\
\hline Prunus avium $\mathbf{L}$. & Tree & Spiral & $2 / 5$ & 5 & 20 & Open \\
\hline Geum canadense Jacq. & Herb & Distichous & $1 / 2$ & 6 & 15 & Intermediate \\
\hline Potentilla fruticosa L. & Shrub & Spiral & $2 / 5$ & 5 & 13 & Open \\
\hline Trifolium repens $\mathbf{L}$. & Herb & Distichous & $1 / 2$ & 4 & 10 & Intermediate \\
\hline
\end{tabular}

and 4. In addition, $\mathrm{A} 2$ and lateral traces $\mathrm{R} 2, \mathrm{R} 4$, $\mathrm{R} 6$, and $\mathrm{R} 8$ are connected at regular intervals by vascular bundles. At nodes 3, 5, and 7 the connecting bundles diverge from the respective lateral traces and fuse to A2. There are no such connections between any of the other trace and axial bundles.

The three traces that supply a particular leaf are parts of three different sympodia. For example, median traces $2,4,6$, and 8 come off axial bundle 1 , and the lateral traces supplying the same leaves diverge from axial bundles 3 and 4 . The lateral traces diverging from $\mathrm{A} 3$, and all median traces, traverse about two internodes whereas laterals from A2 traverse a single internode from the points of their divergence up to the node at which they enter a leaf.

Each axillary bud is supplied by two branch traces each of which diverges from one of the two axial bundles on either side of the median trace which departs at the same node. Accessory bundles, found in large numbers in Cassia, are also present in Trifolium, but in smaller numbers.

The presence of interconnections between sympodia 2 and 3 , but their absence elsewhere in the vascular system of Trifolium, makes it intermediate in structure between the open and closed types.

The vascular system of Geum is characterized by six axial bundles (Fig. 7). A trace bundle diverges from each of the two axial bundles, A1 and $\mathrm{A} 2$, at regular intervals of two internodes: The two trace bundles fuse at a level one internode above their points of divergence, and the bundle thus formed functions as a median trace after traversing one more internode. Median traces originate simultaneously from axial bundles A4 and A5. Each median trace, therefore, has a dual origin. Median traces to successive leaves diverge alternately from these two pairs of axial bundles. From the two remaining axial bundles, namely A3 and A6, lateral leaf traces diverge, one each in every internode. In this vascular system interconnections between axial bundles are established by the pairs of trace bundles which unite to produce the median traces. Consequently, the system becomes closed between the axial bundle pairs of
A1-A2 and A4-A5. The remaining two axial bundles and the lateral leaf traces connected to them do not fuse with each other, or with other bundles of the system. Therefore the vascular system of Geum is, like that of Trifolium, one that is intermediate between the open and closed types.

As in Trifolium, furthermore, there are two types of sympodia in this plant: $1,2,4$, and 5 , each of which consists of an axial bundle and divergent bundles that will fuse to form median traces; and 3 and 6, each of which consists of an axial bundle and lateral traces only. The vascular systems of both Geum and Trifolium reflect the bilateral symmetry of the distichous phyllotaxis.

Discussion-Habit and the primary vascular system-The number and arrangement of the vascular bundles as seen in cross sections vary in the different plants studied (Table 1). Trifolium and Geum are herbs and have 10 and 15 bundles, respectively. The bundles are well separated by interfascicular regions which on the average are $108 \mu$ and $65 \mu$ wide, respectively. Potentilla fruticosa has 13 vascular bundles, which are very compactly arranged. The interfascicular regions are only $5-10 \mu$ wide. (The genus Potentilla is predominantly herbaceous with a plant body similar to that of Geum, but $P$. fruticosa is shrubby, producing a considerable quantity of secondary tissues. Its primary vascular cylinder is smaller than those of the other plants studied herein.) In Prunus, a large tree, there are 20 vascular bundles which are compactly arranged, separated from each other by narrow interfascicular regions $5-10 \mu$ wide. Rubus and Physocarpus are shrubs, and Cassia is a small tree. All are distinctly woody. They have, respectively, 50, 32, and 23 vascular bundles. The interfascicular regions are 5-10 $\mu$ wide. Among the plants that were examined, shrubs and trees have a larger number of vascular bundles than herbs. A compact arrangement of bundles seems to be correlated with arborescence and/or the woody habit.

Large numbers of vascular bundles and their compact disposition in stems have resulted in diverse interpretations of the vascular systems of 
TABLE 2. Data on phyllotaxy and the primary vascular system of the stem in dicotyledons

\begin{tabular}{|c|c|c|c|c|c|c|}
\hline Name & $\begin{array}{l}\text { Phyllo- } \\
\text { tactic } \\
\text { fraction }\end{array}$ & $\begin{array}{c}\text { Number } \\
\text { of } \\
\text { sympodia }\end{array}$ & $\begin{array}{l}\text { Nodal } \\
\text { struc- } \\
\text { ture }\end{array}$ & $\begin{array}{l}\text { Number } \\
\text { of traces } \\
\text { per leaf }\end{array}$ & $\begin{array}{l}\text { Vascular } \\
\text { system } \\
\text { closed/open }\end{array}$ & Source \\
\hline
\end{tabular}

I. Plants with helical (alternate) phyllotaxy:

$\begin{array}{llllll}\text { Petalostemon sp. } & 3 / 8 & 8 & \text { Trilacunar } & 3 & \text { Open } \\ \text { Sutherlandia frutescens } & 3 / 8 & 8 & \text { Trilacunar } & 3 & \text { Open } \\ \text { Acacia baileyana } & 2 / 5 & 5 & \text { Trilacunar } & 3 & \text { Open } \\ \text { Akebia quinata } & 2 / 5 & 5 & \text { Trilacunar } & 3 & \text { Open } \\ \text { Canella alba } & 2 / 5 & 5 & \text { Trilacunar } & 3 & \text { Open } \\ \text { Cocculus trilobus } & 2 / 5 & 5 & \text { Trilacunar } & 3 & \text { Open } \\ \text { Drimys colorata } & 2 / 5 & 5 & \text { Trilacunar } & 3 & \text { Open } \\ \text { Sophora tetraptera } & 2 / 5 & 5 & \text { Trilacunar } & 3 & \text { Open } \\ \text { Warbergia ugandensis } & 2 / 5 & 5 & \text { Trilacunar } & 3 & \text { Open } \\ \text { Salix babylonica } & 1 / 3 & 3 & \text { Trilacunar } & 3 & \text { Open } \\ & & & & & \\ \text { Chenopodium glaucum } & 2 / 5 & 5 & \text { Unilacunar } & 3 & \text { Open } \\ \text { Atriplex sp. } & 2 / 5 & 5 & \text { Unilacunar } & 3 & \text { Open } \\ \text { Iberis amara } & 5 / 13 & 5 & \text { Unilacunar } & 1 & \text { Open } \\ & & & & & \\ \text { Godetia } \text { whitneyi } & 5 / 13 & 5 & \text { Unilacunar } & 1 & \text { Open } \\ & & & & & \\ \text { Suaeda maritima } & 5 / 13 & 5 & \text { Unilacunar } & 1 & \text { Open } \\ & & & & & \\ \text { Kochia } \text { sp. } & 2 / 5 & 5 & \text { Unilacunar } & 1 & \text { Open } \\ \text { Salsola kali } & 2 / 5 & 5 & \text { Unilacunar } & 1 & \text { Open } \\ \text { Suaeda australis } & 2 / 5 & 5 & \text { Unilacunar } & 1 & \text { Open } \\ \text { Hectorella caespitosa } & 5 / 13 & 13 & \text { Unilacunar } & 1 & \text { Closed } \\ \text { Sassafras albidum } & 2 / 5 & 10 & \text { Unilacunar } & 3 & \text { Closed } \\ \text { Bubbia } \text { sp. } & 2 / 5 & 5 & \text { Trilacunar } & 3 & \text { Closed } \\ \text { Linum perenne } & 5 / 13,3 / 8 & & \text { Unilacunar } & 1 & \text { Closed } \\ \text { Linum } \text { usitatissimum } & 5 / 13,3 / 8,2 / 5 & & \text { Unilacunar } & 1 & \text { Closed }\end{array}$

Dormer (1946)

Dormer (1945)

Dormer (1945)

Dormer (1945)

Benzing (1967a,b)

Dormer (1945)

Benzing (1967a,b)

Dormer (1945)

Benzing (1967a,b)

Balfour and Philipson (1962)

Wilson (1924)

Bisalputra (1962)

Balfour and Philipson (1962); De Bary (1884)

Balfour and Philipson (1962)

Balfour and Philipson (1962)

Bisalputra (1962)

Bisalputra (1962)

Bisalputra (1962)

Skipworth (1962)

Benzing (1967a,b)

Benzing (1967a,b)

Esau (1943)

Girolami (1953)

II. Plants with distichous (alternate) phyllotaxy:

\begin{tabular}{|c|c|c|c|c|c|c|}
\hline Eupomatia laurina & $1 / 2$ & & Multilacunar & 7 & Closed & Benzing $(1967 a, b)$ \\
\hline Magnolia virginiana & $1 / 2$ & & Multilacunar & 7 & Closed & Benzing $(1967 a, b)$ \\
\hline Aristolochia clematitis & $1 / 2$ & 4 & Trilacunar & $4^{\mathrm{a}}$ & Closed & Hegedus (1949) \\
\hline Anthyllis vulneraria & $1 / 2$ & 6 & Trilacunar & 3 & Closed & Dormer (1946) \\
\hline Coronilla emerus & $1 / 2$ & 6 & Trilacunar & 3 & Closed & Dormer (1946) \\
\hline C. varia & $1 / 2$ & 6 & Trilacunar & 3 & Closed & Dormer (1946) \\
\hline Doryctnium rectum & $1 / 2$ & 6 & Trilacunar & 3 & Closed & Dormer (1946) \\
\hline D. suffruticosum & $1 / 2$ & 6 & Trilacunar & 3 & Closed & Dormer (1946) \\
\hline Hippocrepis comosa & $1 / 2$ & 6 & Trilacunar & 3 & Closed & Dormer (1946) \\
\hline Lotus corniculatus & $1 / 2$ & 6 & Trilacunar & 3 & Closed & Dormer (1946) \\
\hline L. tetragonolobus & $1 / 2$ & 6 & Trilacunar & 3 & Closed & Dormer (1946) \\
\hline Ornithopus sativus & $1 / 2$ & 6 & Trilacunar & 3 & Closed & Dormer (1946) \\
\hline Securigera coronilla & $1 / 2$ & 6 & Trilacunar & 3 & Closed & Dormer (1946) \\
\hline Scorpiurus sp. & $1 / 2$ & 5 & Trilacunar & 3 & Closed & Dormer (1946) \\
\hline Annona muricata & $1 / 2$ & 4 & Trilacunar & 3 & Closed & Benzing $(1967 \mathrm{a}, \mathrm{b})$ \\
\hline Asimina triloba & $1 / 2$ & 4 & Trilacunar & 3 & Closed & Benzing $(1967 a, b)$ \\
\hline Cananga ordorata & $1 / 2$ & 4 & Trilacunar & 3 & Closed & Benzing $(1967 \mathrm{a}, \mathrm{b})$ \\
\hline Coronilla cappadocica & $1 / 2$ & 4 & Trilacunar & 3 & Closed & Dormer (1946) \\
\hline C. glauca & $1 / 2$ & 4 & Trilacunar & 3 & Closed & Dormer (1946) \\
\hline C. scorpioides & $1 / 2$ & 4 & Trilacunar & 3 & Closed & Dormer (1946) \\
\hline C. valentina & $1 / 2$ & 4 & Trilacunar & 3 & Closed & Dormer (1946) \\
\hline Medicago sp. & $1 / 2$ & 4 & Trilacunar & 3 & Closed & Dormer (1946) \\
\hline Myristica fragrans & $1 / 2$ & 4 & Trilacunar & 3 & Closed & Benzing (1967a,b) \\
\hline Securigera coronilla & $1 / 2$ & 4 & Trilacunar & 3 & Closed & Dormer (1946) \\
\hline Coronilla minima & $1 / 2$ & 3 & Trilacunar & 3 & Closed & Dormer (1946) \\
\hline C. vaginalis & $1 / 2$ & 3 & Trilacunar & 3 & Closed & Dormer (1946) \\
\hline Pterocarpinae & $1 / 2$ & & Trilacunar & 3 & Closed & Dormer (1946) \\
\hline Tephrosia spp. & $1 / 2$ & & Trilacunar & 3 & Closed & Dormer (1946) \\
\hline Vicieae (all except Abrus) & $1 / 2$ & & Trilacunar & 3 & Closed & Dormer (1946) \\
\hline
\end{tabular}


TABle 2. Continued

\begin{tabular}{|c|c|c|c|c|c|c|}
\hline Name & $\begin{array}{l}\text { Phyllo- } \\
\text { tactic } \\
\text { fraction }\end{array}$ & $\begin{array}{c}\text { Number } \\
\text { of } \\
\text { sympodia }\end{array}$ & $\begin{array}{l}\text { Nodal } \\
\text { struc- } \\
\text { ture }\end{array}$ & $\begin{array}{l}\text { Number } \\
\text { of traces } \\
\text { per leaf }\end{array}$ & $\begin{array}{l}\text { Vascular } \\
\text { system } \\
\text { closed/open }\end{array}$ & Source \\
\hline \multicolumn{7}{|c|}{ III. Plants with decussate (opposite) phyllotaxy: } \\
\hline Cercidiphyllum japonicum & $1 / 2$ & 4 & Trilacunar & 3 & Closed & Benzing $(1967 a, b)$ \\
\hline Garrya elliptica & $1 / 2$ & & Trilacunar & 3 & Closed & $\begin{array}{l}\text { Balfour and Philipson } \\
(1962)\end{array}$ \\
\hline Hedycaria angustifolia & $1 / 2$ & 8 & Unilacunar & 7 & Closed & Benzing $(1967 \mathrm{a}, \mathrm{b})$ \\
\hline Xymalos monospora & $1 / 2$ & 8 & Unilacunar & 7 & Closed & Benzing $(1967 a, b)$ \\
\hline Calycanthus floribundus & $1 / 2$ & 8 & Unilacunar & 3 & Closed & Benzing $(1967 \mathrm{a}, \mathrm{b})$ \\
\hline Ascarina lucida & $1 / 2$ & 4 & Unilacunar & 2 & Open & $\begin{array}{l}\text { Balfour and Philipson } \\
\text { (1962) }\end{array}$ \\
\hline Ascarina sp. & $1 / 2$ & 4 & Unilacunar & 2 & Open & Swamy (1953) \\
\hline Clerodendron trichotomum & $1 / 2$ & 4 & Unilacunar & 2 & Open & $\begin{array}{l}\text { Marsden and Bailey } \\
(1955)\end{array}$ \\
\hline Coleus blumei & $1 / 2$ & 4 & Unilacunar & 2 & Closed & $\begin{array}{l}\text { Balfour and Philipson } \\
\text { (1962) }\end{array}$ \\
\hline Anabasis articulata & $1 / 2$ & 2 & Unilacunar & 1 & Closed & Fahn and Arzee (1959) \\
\hline Arthrocnemum glaucum & $1 / 2$ & 4 & Unilacunar & 1 & Open & Fahn and Arzee (1959) \\
\hline Salicornia australis & $1 / 2$ & 4 & Unilacunar & 1 & Closed & Bisalputra (1962) \\
\hline
\end{tabular}

${ }^{a}$ Median trace is double.

many dicotyledons. In several woody ranalian plants primary vascular systems have been described as pseudosiphonostelic because "the primary xylem tends to be more or less loosely and uniformly distributed" (Bailey and Nast, 1948); or, because "the primary vascular system consists of a continuous cylinder of procambium" (Wilson, 1924; Benzing, 1967b). However, this study has shown that the seemingly compact and continuous vascular systems may consist of vascular bundles which are discrete entities that can be traced as such in serial sections through successive internodes. It is also significant to note that in every case where developmental studies of primary vasculature have been made, the vascular bundles are found to differentiate as independent strands. This is the case not only in herbs with obviously discrete bundles but also in herbaceous and woody species which have a compactly arranged primary vascular system (Balfour and Philipson, 1962; Benzing, 1967a, b; Devadas and Beck, 1971).

The total number of vascular bundles in a plant is directly related to the number of axial bundles, the number of traces per leaf, and the number of internodes traversed by the leaf traces in the stem. As traces traverse more internodes, they overlap each other and bring about an increase in the number of bundles. The number of bundles as seen in cross sections is about 50 in Rubus, 32 in Physocarpus, 23 in Cassia, and 20 in Prunus. The leaf trace bundles in these plants traverse 8-35, $5-17,5-8$, and 5-7 internodes, respectively. Similarly, Potentilla and Geum have about 15, Trifolium 10, vascular bundles; the leaf trace bundles traverse 1-4 internodes in the first two plants and 1-2 internodes in Trifolium.

Vascular system and phyllotaxy-Because of the structural and functional unity between the stem and the leaves there is an obvious relationship between the arrangement of leaves on the stem and its vascular system. The data given in Table 2 were gathered from the literature. In plants which have helically arranged leaves, the vascular system is predominantly of the open type, and more than half the plants in this sample have a 3-trace, trilacunar nodal anatomy. The number of sympodia does not correspond in all cases with the number of orthostichies. But it is significant to note that in every case where the leaves have three traces and the vascular system is open, the number of sympodia coincide with the number of orthostichies (which is also the denominator of the phyllotactic fraction). This correlation is illustrated and further strengthened by the vascular patterns in the five woody species we have studied (Table 1). Of the total of 15 species with these characteristics included in Tables 1 and 2, 14 are woody. Of these, five are in the Ranales, four in the Rosaceae, four in the Leguminosae, and one in the Amentiferae. All species are considered to be primitive or relatively primitive. In other plants of this sample, there is no such constant relationship between the number of sympodia and the number of orthostichies. Because of its association with arborescence, or at least the woody habit, and its occurrence in families which are generally considered primitive, it seems reasonable to suggest that the open type of vascular system in which the number of sympodia correspond to the number of orthostichies is a basic and primitive type in the dicotyledons.

In plants of this sample with decussate leaves the vascular systems are mostly closed and the nodes are predominantly unilacunar. Sympodia 
occur in even numbers of 2,4 , and 8 . In those with distichous leaves, the vascular system is closed, the nodes are in most cases trilacunar, and the leaves have three traces. The number of sympodia varies from 3 to 6 . By contrast, the two plants with distichous phyllotaxy in our study, Trifolium and Geum, are characterized by a vascular system that is intermediate between the open and closed types.

Interpretations of the primary vascular system -Namboodiri and Beck (1968a, b, c) studied the primary vascular systems of 30 species in 23 genera of living conifers and found that the vascular bundles comprise sympodial systems. In 23 species which have helically arranged leaves, there are 8-21 discrete sympodia in the stem, lacking completely any interconnections. From axial bundles leaf traces diverge at regular intervals without causing any interruption in the sympodial systems. A survey of the fossil record by the same authors has revealed that a vascular system of a similar construction apparently existed also in coniferophytic progymnosperms like Archaeopteris. A comparable vascular system has been described in Calamopitys of the Calamopityaceae (Beck, 1970) as well as in the primitive gymnosperm Lyginopteris (Scott, 1923; Louvel, 1960; Blanc-Louvel, 1966; Beck, 1970).

The basic construction of the primary vascular system of the dicotyledons studied in this work is essentially identical to that of the conifers described by Namboodiri and Beck (1968a, b, c) and the primitive groups mentioned above. In both gymnosperms and angiosperms the vascular systems consist of discrete sympodia, each of which consists of an axial bundle from which leaf traces diverge.

Although a comparison of conifers and dicotyledons with helically arranged alternate leaves and open primary vascular systems shows many similarities, there are also some conspicuous differences. For example, leaf traces of conifers traverse less than one internode before entering a leaf base whereas those of dicotyledons traverse one or more internodes (1-35 in different species). Furthermore, out of a total of 15-23 vascular bundles in cross sections of different conifers, there are 5-21 axial bundles (commonly 8 or 13) (Namboodiri and Beck, 1968a), whereas out of a total of 10-50 vascular bundles in cross sections of different species of dicotyledons, there are 3-13 axial bundles (commonly 5).

The larger number of vascular bundles in dicots is related to the larger number of leaf traces per leaf and the traversal by leaf traces of a greater number of internodes than in the conifers. The predominantly larger number of traces per leaf in dicots may be due to the larger size of the leaves in this group.

Leaf gaps (of filicinean type) are often con- sidered to be present in the vascular systems of seed plants (see Foster and Gifford, 1959). The present work and those of Balfour and Philipson (1962), Esau (1965a, b), and others have shown, however, that in many seed plants the eustele consists of discrete sympodia in which leaf gaps are not easily definable. "In systems composed of bundles clearly separated from one another by interfascicular regions of parenchyma (medullary rays) the gaps are confluent with these regions on the sides of leaf insertions in closed systems; and above the leaf insertions as well in open systems. Thus, the delimitation of the leaf gap in the primary body is highly artificial. . ." (Esau, 1965b). The mere occurrence, however, of sympodia and morphologically vaguely defined leaf gaps is not in itself evidence that the eustele was not derived from the siphonostele since such characteristics could have resulted simply from extreme reduction. In fact, the continued acceptance of the leaf gap concept in seed plants is based primarily on this assumption.

Many morphologists today reject the idea that angiosperms might have evolved directly or indirectly from some filicinean ancestor and, instead, believe it is more reasonable to accept a group of gymnosperms as ancestral to them (see Delevoryas, 1962; Beck, 1966; Takhtajan, 1969). It is, furthermore, questionable whether the leaf gaps of seed plants are morphologically equivalent to those of ferns. Recent interpretations of the eustele in gymnosperms by Namboodiri and Beck (1968a, b, c) and Beck (1970) militate against the presence of either a filicinean type of siphonostele or filicinean leaf gaps in gymnosperms. These authors present evidence which they interpret as showing that the eustele in calamopityean progymnosperms and the lyginopterid gymnosperms evolved directly from a protostele through longitudinal dissection without any intervening siphonostelic stage. The sympodial systems thus formed are clearly defined in such primitive gymnosperms as Calamopitys foerste ${ }^{2}$ (Beck, 1970) and Lyginopteris oldhamia (Scott, 1923; Louvel, 1960), and they are basically identical with those of the woody angiosperms described herein and by other authors. On the basis of this interpretation there would seem to be no leaf gaps of the filicinean type in the eustele of Lyginopteris. If one accepts the view that the angiosperms most likely evolved from a group of pteridosperms, then it follows that there may be no leaf gaps of the fern type in angiosperms as well, a view expressed earlier by Sporne (1958). This view has also been supported recently by Slade (1971).

If we accept, therefore, the suggestion that the sympodia of angiosperms, like those of Lyginop-

\footnotetext{
${ }^{2}$ Since this Lower Mississippian genus is known only from structurally preserved segments of stems it is not certain that it was a seed-producing gymnosperm. If not, it was very likely a progymnosperm (Beck, 1966).
} 
teris, may have evolved from a protostele by way of some similar pteridosperm, one must conclude that the continuing bundles of the sympodia from which leaf traces diverge are cauline. The protostele is clearly an axial, not a foliar structure. That this is true becomes very apparent when one considers that the ancestral psilophytes from which the protostelic progymnosperms must have evolved were leafless. It is for these reasons, therefore, that we refer to the main bundle of the sympodium as an axial bundle and consider that leaf traces are branches from them. This interpretation is consonant with that of Dormer $(1945,1954)$ and Bisalputra (1962) but at variance with the viewpoint of Nast (1944), O'Neill (1961), Philipson and Balfour (1963), and Esau (1965b) that the sympodia are composed solely of leaf traces.

\section{LITERATURE CITED}

Bailey, I. W., and C. G. NAST. 1948. Morphology and relationships of Illicium, Schisandra and Kadsura. I. Stem and leaf. J. Arnold Arboretum 29: $77-89$.

Balfour, E. E., AND W. R. Philipson. 1962. The development of the primary vascular system of certain dicotyledons. Phytomorphology 12: 110-143.

BECK, C. B. 1966 . On the origin of gymnosperms. Taxon 15: 337-339.

- 1970. The appearance of gymnospermous structure. Biol. Rev. 45: 379-400.

BenZING, D. H. 1967a. Developmental patterns in stem primary xylem of woody Ranales. I. Species with unilacunar nodes. Amer. J. Bot. 54: 805-813.

- $1967 \mathrm{~b}$. Developmental patterns in stem primary xylem of woody Ranales. II. Species with trilacunar and multilacunar nodes. Amer. J. Bot. 54: $813-820$.

Bisalputra, T. 1962. Anatomical and morphological studies in the Chenopodiaceae. III. The primary vascular system and nodal anatomy. Aust. J. Bot. 10: $13-24$.

Blanc-Louvel, C. 1966. Étude anatomique comparée des tiges et des pétioles d'une ptáridospermes du carbonifère du genre Lyginopteris Potonie. Mém. Mus. Nat. Hist. Natur. Ser. C. 18: 1-103.

Bower, F. O. 1923. The ferns. Vol. I. Analytical examination of the criteria of comparisons. Cambridge University Press, London.

BREBNER, G. 1902. On the anatomy of Danaea and other Marattiaceae. Ann. Bot. 16: 517-552.

DE BARY, A. 1884. Comparative anatomy of the vegetative organs of phanerogams and ferns. English transl. by F. O. Bower and D. H. Scott. Clarendon Press, Oxford.

Delevoryas, T. 1962. Morphology and evolution of fossil plants. Holt, Rinehart and Winston, New York.

Devadas, S. C. 1970. A comparative study of development and morphology of the primary vascular system of some species of Leguminosae and Rosaceae. Ph.D. Thesis. University of Michigan, Ann Arbor.

- AND C. B. BECK. 1971. Development and morphology of stelar components in the stems of some members of the Leguminosae and Rosaceae. Amer. J. Bot. 58: 432-446.
DoRMER, K. J. 1945. An investigation of the taxonomic value of shoot structure in angiosperms with special reference to Leguminosae. Ann. Bot. 9: 141-153.

- 1946. Vegetative morphology as a guide to the classification of the Papilionatae. New Phytol. 45: $145-161$.

- 1954. The acacian type of vascular system and some of its derivatives. I. Introduction, Menispermaceae, Lardizabalaceae and Berberidaceae. New Phytol. 53: 301.

EsAU, K. 1943. Vascular differentiation in the vegetative shoot of Linum. II. The first phloem and xylem. Amer. J. Bot. 30: 248-255.

- 1965a. Plant Anatomy. 2nd ed. John Wiley and Sons, New York.

- 1965b. Vascular differentiation in plants. Holt, Rinehart and Winston, New York.

FAHN, A., AND T. ARZEE. 1959. Vascularization of articulated Chenopodiaceae and the nature of their fleshy cortex. Amer. J. Bot. 46: 330-338.

Foster, A. S., AND E. M. Gifford, JR. 1959. Comparative morphology of vascular plants. W. H Freeman, San Francisco.

GeYlER, H. T. 1867. Ueber den Gefässbündelverlauf in den Laubblattregionen der Coniferen. Jahrb. Wiss. Bot. 6: 55-208.

Girolami, G. 1953. Relation between phyllotaxy and primary vascular organization in Linum. Amer. J. Bot. 40: 618-625.

GwYNne-Vaughan, D. T. 1901. Observations on the anatomy of solenostelic ferns. Ann. Bot. 15: 71-98.

HEgEDUS, A. 1949. Is there a correlation between leaf arrangement and the manner of ontogeny of the conductive tissues of stems? Bot. Gaz. 110: 593600.

JEFFREY, E. C. 1898-99. The morphology of the central cylinder in the angiosperms. Trans. Can. Inst., Toronto 6: 599-636.

- 1902. The structure and development of the stem in the Pteridophyta and gymnosperms. Phil. Trans. Roy. Soc. London 195B: 119-146.

Jensen, L. C. W. 1968. Primary stem vascular patterns in three subfamilies of the Crassulaceae. Amer. J. Bot. 55: 553-563.

Kumari, G. K. 1963. The primary vascular system of gymnosperms. Ph.D. Thesis. University of Michigan, Ann Arbor.

Louvel, C. 1960. Ramification d'une tige principale de Lyginopteris oldhamia Binney. Bull. Soc. Géol. France. $7^{\mathrm{e}}$ ser. 2: 666-672.

Marsden, M. P. F., ANd I. W. Balley. 1955. A fourth type of nodal anatomy in dicotyledons, illustrated by Clerodendron trichotomum. J. Arnold Arboretum 36: 1-51.

NäGELI, C. 1858. Beiträge zur Wissenschaftlichen Botanik, Part I. Engelman, Leipzig.

NAMboodiri, K. K., AND C. B. BECK. 1968a. A comparative study of the primary vascular system of conifers. I. Genera with helical phyllotaxis. Amer. J. Bot. 55: 447-457.

— AND 1 1968b. A comparative study of the primary vascular system of conifers. II. Genera with opposite and whorled phyllotaxis. Amer. J. Bot. 55: $458-463$.

—— AND — 1968c. A comparative study of the primary vascular system of conifers. III. Stelar 
evolution in gymnosperms. Amer. J. Bot. 55: 464472.

NAST, C. G. 1944. The comparative morphology of the Winteraceae. VI. Vascular anatomy of the flowering shoot. J. Arnold Arboretum 25: 454466.

O'NeILl, T. B. 1961. Primary vascular organization of Lupinus shoot. Bot. Gaz. 123: 1-9.

Philipson, W. R., AND E. E. Balfour. 1963. Vascular patterns in dicotyledons. Bot. Rev. 29: 382-404.

ScoTT, D. H. 1923. Studies in fossil botany, Vol. II. 3rd ed. A. \& C. Black, London.

SkIPWORTH, J. P. 1962. The primary vascular system and phyllotaxis in Hectorella caespitosa Hook. ff. N. Z. J. Sci. 5: 253-258.

Slade, Brenda F. 1971. Stelar evolution in vascular plants. New Phytol. 70: 879-884.
SPORNE, K. R. 1958. Some aspects of floral vascular systems. Proc. Linnean Soc. London 69: 75-84.

Strasburger, E. 1891. Úber den Bau und die Verrichtungen der Leitungsbahnen in den Pflanzen. Histologische Beiträge, Band 3. G. Fischer, Jena.

Swamy, B. G. L. 1953. The morphology and relationships of the Chloranthaceae. J. Arnold Arboretum 34: $375-408$.

TAKHTAJAN, A. 1969. Flowering plants, origin and dispersal. Oliver and Boyd Ltd., Edinburgh.

VAN Tieghem, P., and $H$. Douliot. 1886. Sur la polystelie. Ann. Sci. Natur., Bot. $7^{\circ}$ ser. 3: 275-322.

WiLson, C. L. 1924. Medullary bundle in relation to primary vascular system in Chenopodiaceae and Amaranthaceae. Bot. Gaz. 78: 175-199.

ZimmermanN, W. 1930 . Die phylogenie der pflanzen. G. Fischer, Jena. 